\title{
Reclassification of Salegentibacter catena Ying et al. 2007 as Salinimicrobium catena gen. nov., comb. nov. and description of Salinimicrobium xinjiangense sp. nov., a halophilic bacterium isolated from Xinjiang province in China
}

\author{
Correspondence \\ Chang-Jin Kim \\ changjin@kribb.re.kr
}

\author{
Jee-Min Lim, ${ }^{1} \dagger$ Che Ok Jeon, ${ }^{2} \dagger$ Seung Sik Lee, ${ }^{2}$ Dong-Jin Park, ${ }^{1}$ \\ $\mathrm{Li}-\mathrm{Hua} \mathrm{Xu}^{3}{ }^{3}$ Cheng-Lin Jiang ${ }^{3}$ and Chang-Jin Kim ${ }^{1}$ \\ ${ }^{1}$ Korea Research Institute of Bioscience and Biotechnology, 52 Oeundong, Yusong, \\ Daejeon 305-333, Republic of Korea
${ }^{2}$ Division of Applied Life Science, EB-NCRC, PMBBRC, Gyeongsang National University, Jinju, 660-701, Republic of Korea \\ ${ }^{3}$ Yunnan Institute of Microbiology, Yunnan University, Kunming, Yunnan, 650091, PR China
}

\begin{abstract}
A Gram-negative, non-motile and moderately halophilic rod-shaped bacterium, designated strain $\mathrm{BH}^{206}{ }^{\top}$, was isolated from a saline lake of Xinjiang province in China. The isolate showed catalase-positive and oxidase-negative reactions and did not reduce nitrate. Phylogenetic analysis based on 16S rRNA gene sequences showed that the isolate was most closely related to [Salegentibacter] catena $\mathrm{HY}_{1}^{\top}$ with $95.8 \% 16 \mathrm{~S}$ rRNA gene sequence similarity, and formed a tight phyletic group with [Salegentibacter] catena $\mathrm{HY}^{\top}{ }^{\top}$ with a bootstrap value of $99 \%$ within the family Flavobacteriaceae. However, strain $\mathrm{BH}_{20} 6^{\top}$ and [Salegentibacter] catena $\mathrm{HY} 1^{\top}$ formed a phyletic lineage distinct from other Salegentibacter species. The 16S rRNA gene sequence similarities of strain $\mathrm{BH}_{206}{ }^{\top}$ with other related type species were lower than $94.6 \%$. On the basis of physiological and molecular properties, it is clear that [Salegentibacter] catena should be reclassified in the new genus Salinimicrobium as Salinimicrobium catena gen. nov., comb. nov. (type strain $\mathrm{HY}^{\top}=\mathrm{CGMCC} 1.6101^{\top}=\mathrm{JCM} 14015^{\top}$ ) and that strain $\mathrm{BH} 206^{\top}$ represents a novel species within the genus Salinimicrobium, for which the name Salinimicrobium xinjiangense sp. nov. is proposed. The type strain of Salinimicrobium xinjiangense is $\mathrm{BH} 206^{\top}$ $\left(=\right.$ KCTC $12883^{\top}=$ DSM $\left.19287^{\top}\right)$.
\end{abstract}

The genus Salegentibacter, a member of the family Flavobacteriaceae, was first proposed by McCammon \& Bowman (2000) to accommodate moderately halophilic, yellow-pigmented, non-gliding bacteria that were isolated from a hypersaline meromictic lake in Antarctica. At the time of writing, the genus comprises five recognized species, Salegentibacter holothuriorum, isolated from the edible holothurian Apostichopus japonicus (Nedashkovskaya et al.,

†These authors contributed equally to this work.

Abbreviations: NJ, neighbour-joining; ML, maximum-likelihood; MP, maximum-parsimony.

The GenBank/EMBL/DDBJ accession number for the 16S rRNA gene sequence of strain $\mathrm{BH}_{206}{ }^{\top}$ is EF520007.

A transmission electron micrograph of cells of strain $\mathrm{BH}_{20} \mathrm{O}^{\top}$ and a table showing the cellular fatty acid composition of strain $\mathrm{BH}_{20} \mathrm{O}^{\top}$ and related type strains are available as supplementary material with the online version of this paper.
2004), Salegentibacter mishustinae, from the sea urchin Strongylocentrotus intermedius (Nedashkovskaya et al., 2005a), Salegentibacter agarivorans, associated with a sponge (Nedashkovskaya et al., 2006), and Salegentibacter flavus (Ivanova et al., 2006) and [Salegentibacter] catena (Ying et al., 2007) from sea sediment.

In the course of screening halophilic bacteria, a nonmotile, Gram-negative, moderately halophilic bacterium, designated strain $\mathrm{BH} 206^{\mathrm{T}}$, was isolated from soil sediment of a salt lake. Comparative analysis of $16 \mathrm{~S}$ rRNA gene sequences indicated that the closest relative of strain $\mathrm{BH}_{206}{ }^{\mathrm{T}}$ was [Salegentibacter] catena $\mathrm{HY}^{\mathrm{T}}{ }^{\mathrm{T}}$, with $95.8 \% 16 \mathrm{~S}$ rRNA gene sequence similarity, and strain $\mathrm{HY}^{\mathrm{T}}$ should be reclassified as a new genus on the basis of phylogenetic and phenotypic characteristics.

Strain $\mathrm{BH}_{206^{\mathrm{T}}}$ was isolated on marine agar 2216 (MA; Difco) with the addition of $8 \%(\mathrm{w} / \mathrm{v}) \mathrm{NaCl}$ [final 
concentration: $10.94 \%(\mathrm{w} / \mathrm{v}) \mathrm{NaCl}$ ] from a salt lake in Xinjiang province in China. After isolation, the novel strain was cultivated at $32{ }^{\circ} \mathrm{C}$ for 2 days on MA and stored at $-80{ }^{\circ} \mathrm{C}$ in marine broth (Difco) supplemented with $10 \%$ (v/v) glycerol. Except where indicated, the isolate was routinely grown aerobically on MA for 2 days at $32{ }^{\circ} \mathrm{C}$. Requirement for and tolerance of $\mathrm{NaCl}$ was determined at $0.5 \%$ increments in MH medium (Carrasco et al., 2006) [0-14\% (w/v) NaCl, $0.7 \mathrm{~g} \mathrm{MgCl}_{2}, 0.96 \mathrm{~g} \mathrm{MgSO}_{4}, 0.036 \mathrm{~g}$ $\mathrm{CaCl}_{2}, 0.2 \mathrm{~g} \mathrm{KCl}, 0.006 \mathrm{~g} \mathrm{NaHCO}_{3}, 0.0026 \mathrm{~g} \mathrm{NaBr}, 1 \mathrm{~g}$ yeast extract (Difco), $0.5 \mathrm{~g}$ proteose peptone no. 3 (Difco) and $0.1 \mathrm{~g}$ glucose per litre]. Growth was examined at different temperatures $\left(5-55{ }^{\circ} \mathrm{C}\right.$ at $5{ }^{\circ} \mathrm{C}$ increments $)$ and $\mathrm{pH}$ values (5.0-11.0 at $0.5 \mathrm{pH}$ unit increments) in marine broth (Gomori, 1955). Anaerobic growth was determined by incubation in an anaerobic chamber at $32{ }^{\circ} \mathrm{C}$ for 5 days on MA. After 2 days incubation at $32{ }^{\circ} \mathrm{C}$ on MA, strain $\mathrm{BH} 206^{\mathrm{T}}$ formed yellow, circular, smooth, glistening and convex colonies. The strain grew in $\mathrm{MH}$ medium with the addition of $0.5-10 \%(\mathrm{w} / \mathrm{v}) \mathrm{NaCl}$ and optimum growth occurred at $2-3 \%(\mathrm{w} / \mathrm{v}) \mathrm{NaCl}$. Growth was observed at temperatures between 10 and $48{ }^{\circ} \mathrm{C}$, with an optimum growth temperature of $32-35{ }^{\circ} \mathrm{C}$, and from $\mathrm{pH} 6.0$ to 9.0 (optimum, $\mathrm{pH}$ 7.5-8.0). Anaerobic growth was observed after 5 days at $32{ }^{\circ} \mathrm{C}$ on MA.

Gram-staining was determined using the bioMérieux Gram stain kit according to the manufacturer's instructions. Oxidase activity was tested using Bactident oxidase strip (Merck) and catalase activity was determined by bubble production in $3 \%(\mathrm{v} / \mathrm{v})$ hydrogen peroxide solution. The production of flexirubin-type pigments was investigated using $\mathrm{KOH}$, following the requirements specified in the minimal standards for the description of new taxa in the family Flavobacteriaceae (Bernardet et al., 2002). Nitrate reduction and hydrolysis of starch, aesculin, CM-cellulose, urea, casein, Tween 80, hypoxanthine, L-tyrosine and xanthine were determined on MA or in marine broth according to the methods described previously (Lanyi, 1987; Smibert \& Krieg, 1994). Acid production from galactose, D-glucose, lactose, maltose, mannose, L-arabinose, D-fructose, glycerol, D-mannitol, melibiose, raffinose, salicin and sucrose was determined as described by Leifson (1963). Additional enzyme activities were determined using API ZYM strips (bioMérieux) at $32{ }^{\circ} \mathrm{C}$. Cell morphology, flagella and gliding motility were studied using phase-contrast microscopy and transmission electron microscopy (JEM-1010; JEOL) as described previously (Bernardet et al., 2002; Jeon et al., 2005). Strain BH206 ${ }^{\mathrm{T}}$ was Gram-negative, catalase-positive, oxidase-negative and did not reduce nitrate to nitrite. Cells of the isolate were non-motile rods $(0.6-1.0 \mu \mathrm{m}$ wide and $1.2-2.4 \mu \mathrm{m}$ long) (Supplementary Fig. S1; available in IJSEM Online). Strain $\mathrm{BH}^{206^{\mathrm{T}}}$ hydrolysed aesculin, casein, starch and L-tyrosine, but hydrolysis of CM-cellulose, hypoxanthine, Tween 80 , xanthine and urea was not observed. Other phenotypic features of strain $\mathrm{BH} 206^{\mathrm{T}}$ are presented in Table 1 and in the description of the novel species.
Whole-cell fatty acids of strain $\mathrm{BH} 206^{\mathrm{T}}$ were analysed according to the instructions of the Microbial Identification System (MIDI; Microbial ID) after cultivation on MA for 2 days at $32{ }^{\circ} \mathrm{C}$. Analyses of polar lipids and isoprenoid quinones were carried out using the methods described by Komagata \& Suzuki (1987). The genomic DNA G $+\mathrm{C}$ content of strain $\mathrm{BH} 206^{\mathrm{T}}$ was determined using an HPLC fitted with a reversed-phase column (GROM-SIL 100 ODS-2FE; GROM) according to the method of Tamaoka \& Komagata (1984). The major respiratory lipoquinone of strain $\mathrm{BH} 206^{\mathrm{T}}$ was menaquinone-6 (MK-6). The predominant cellular fatty acids of strain $\mathrm{BH}_{206^{\mathrm{T}}}$ were iso- $\mathrm{C}_{15: 0}(16.17 \%)$, anteiso- $\mathrm{C}_{15: 0}$ $(11.98 \%)$, iso- $\mathrm{C}_{16: 0}(10.21 \%)$, iso- $\mathrm{C}_{17: 1} \omega 9 c(8.66 \%)$, iso$\mathrm{C}_{17: 0} 3-\mathrm{OH}(8.18 \%)$ and summed feature $3(6.78 \%)$, comprising $\mathrm{C}_{16: 1} \omega 7 \mathrm{c}$ and/or iso- $\mathrm{C}_{15: 0} \quad 2-\mathrm{OH}$, which resemble those determined for other related type strains in the family Flavobacteriaceae (Supplementary Table S1). The major polar lipid of the test strain was phosphatidylethanolamine (PE). The genomic DNA G $+\mathrm{C}$ content of strain $\mathrm{BH} 206^{\mathrm{T}}$ was $42.1 \mathrm{~mol} \%$. A study of the phenotype of strain $\mathrm{BH} 206^{\mathrm{T}}$ is summarized and compared with that of phylogenetically related type relatives in Table 1 . Many of them are in accordance with those of [Salegentibacter] catena $\mathrm{HY} 1^{\mathrm{T}}$ and allow the differentiation of strain $\mathrm{BH} 206^{\mathrm{T}}$ and [Salegentibacter] catena $\mathrm{HY}_{1}^{\mathrm{T}}$ from Salegentibacter species.

The sequencing and assembly of the 16S rRNA gene of strain $\mathrm{BH} 206^{\mathrm{T}}$ was carried out as described previously (Lane, 1991). The resulting 16S rRNA gene sequence (1404 nt) of strain $\mathrm{BH} 206^{\mathrm{T}}$ was compared with available $16 \mathrm{~S}$ rRNA gene sequences from GenBank using the BLAST program (http://www.ncbi.nlm.nih.gov/BLAST/) to determine an approximate phylogenetic affiliation, and gene sequences were aligned with those of closely related species by using the CLUSTAL w software program (Thompson et al., 1994). Phylogenetic trees were constructed using three different methods, neighbour-joining (NJ), maximumlikelihood (ML) and maximum-parsimony (MP) algorithms, which are available in the PHYLIP software, version 3.6 (Felsenstein, 2002). Sequence similarity values were computed using Similarity Matrix version 1.1 (Ribosomal Database Project II; http://rdp.cme.msu.edu/; Cole et al., 2003) between the novel strain and other related members. Bootstrap analysis was performed according to the Kimura two-parameter model (Kimura, 1980) of the NJ method in the PHYLIP package. Phylogenetic analysis based on the $16 \mathrm{~S}$ rRNA gene sequences indicated that the isolate was most closely related to [Salegentibacter] catena $\mathrm{HY}^{\mathrm{T}}$, with $95.8 \%$ $16 \mathrm{~S}$ rRNA gene sequence similarity, and formed a tight phyletic group with [Salegentibacter] catena $\mathrm{HY}^{\mathrm{T}}$ with $99 \%$ bootstrap value within the family Flavobacteriaceae (Fig. 1). However, strain $\mathrm{BH}_{206^{\mathrm{T}}}$ and [Salegentibacter] catena $\mathrm{HY}_{1}^{\mathrm{T}}$ formed a phyletic lineage distinct from other Salegentibacter species. The $16 \mathrm{~S}$ rRNA gene sequence similarities of strain $\mathrm{BH} 206^{\mathrm{T}}$ with other related type species were lower than $94.6 \%$. The overall topology of the ML and MP trees were essentially the same as that of 
Table 1. Phenotypic characteristics of strain $\mathrm{BH}_{20}{ }^{\top}$ and other related type strains

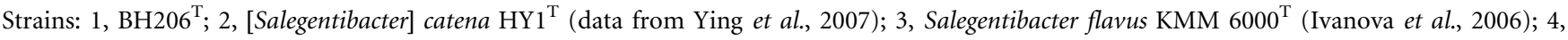
Salegentibacter salegens DSM 5424 ${ }^{\mathrm{T}}$ (Dobson et al., 1993); 5, Gillisia mitskevichiae KCTC $12261^{\mathrm{T}}$ (Nedashkovskaya et al., 2005b); 6, Mesonia algae KCTC $12089^{\mathrm{T}}$ (Nedashkovskaya et al., 2003). All strains are positive for catalase activity and hydrolysis of gelatin and negative for flexirubin pigments and gliding motility. + , Positive; -, negative; w, weak; ND, no data.

\begin{tabular}{|c|c|c|c|c|c|c|}
\hline Characteristic & 1 & 2 & 3 & 4 & 5 & 6 \\
\hline Oxidase & - & - & + & + & + & + \\
\hline Nitrate reduction & - & - & - & + & - & - \\
\hline \multicolumn{7}{|l|}{ Growth at: } \\
\hline $37{ }^{\circ} \mathrm{C}$ & + & + & - & - & - & - \\
\hline $15 \% \mathrm{NaCl}$ & - & - & - & + & - & + \\
\hline Appendages & - & + & - & - & ND & $\mathrm{ND}$ \\
\hline \multicolumn{7}{|l|}{ Hydrolysis of: } \\
\hline Casein & + & + & - & - & + & + \\
\hline DNA & - & - & ND & + & + & - \\
\hline Starch & + & + & + & + & - & - \\
\hline Urea & - & - & + & - & + & - \\
\hline \multicolumn{7}{|l|}{ Acid from: } \\
\hline Arabinose & - & - & - & + & - & - \\
\hline Galactose & $\mathrm{W}$ & - & ND & $\mathrm{ND}$ & - & - \\
\hline Glucose & + & + & $\mathrm{ND}$ & + & + & - \\
\hline Lactose & + & - & ND & - & - & - \\
\hline Maltose & + & - & $\mathrm{ND}$ & + & - & - \\
\hline $\mathrm{H}_{2} \mathrm{~S}$ production & - & + & - & - & - & + \\
\hline Major fatty acids & $\begin{array}{l}\text { iso- } \mathrm{C}_{15: 0}, \\
\text { anteiso- } \mathrm{C}_{15: 0}, \\
\text { iso- } \mathrm{C}_{16: 0}\end{array}$ & iso- $\mathrm{C}_{16: 0}, \mathrm{C}_{15: 0}$ & $\begin{array}{l}\text { anteiso- } C_{15: 0}, \\
C_{15: 0}, \text { iso- } C_{16: 0}\end{array}$ & $\begin{array}{l}\text { iso- } \mathrm{C}_{15: 1} \text {, iso- } \mathrm{C}_{15: 0} \\
\quad \text { anteiso- } \mathrm{C}_{15: 0}\end{array}$ & $\begin{array}{c}\text { iso- } \mathrm{C}_{15: 1}, \\
\text { summed feature } 3, \\
\text { iso- } \mathrm{C}_{15: 0}\end{array}$ & $\begin{array}{l}\text { iso- } \mathrm{C}_{15: 0}, \\
\text { iso- } \mathrm{C}_{17: 0} 3-\mathrm{OH} \text {, } \\
\text { iso- } \mathrm{C}_{16: 0}\end{array}$ \\
\hline $\begin{array}{l}\text { DNA G + C content } \\
(\mathrm{mol} \%)\end{array}$ & 42.1 & 44.4 & 40.4 & $37-38$ & 36.4 & $32-34$ \\
\hline
\end{tabular}

the NJ tree (data not shown). The chemotaxonomic and molecular characteristics and phylogenetic properties described here showed that strain $\mathrm{BH} 206^{\mathrm{T}}$ and [Salegentibacter] catena should be described as members of the same genus in the family Flavobacteriaceae, and that they are distinguishable from other closely related genera (Bernardet et al., 2002; Van Trappen et al., 2004; Ying et al. 2007). Therefore, we propose the reclassification of [Salegentibacter] catena to the genus Salinimicrobium as Salinimicrobium catena gen. nov., comb. nov. In addition, strain $\mathrm{BH} 206^{\mathrm{T}}$ represents a novel species in the genus Salinimicrobium, for which the name Salinimicrobium xinjiangense sp. nov. is proposed.

\section{Description of Salinimicrobium gen. nov.}

Salinimicrobium (Sa.li.ni.mi.cro'bi.um. L. pl. n. salinae salt-works, salt-pits; N.L. neut. n. microbium microbe; N.L. neut. n. Salinimicrobium small, saline microbe).

Cells are Gram-negative, non-spore-forming rods. Catalase-positive and oxidase-negative. Colonies are yellow pigmented. No flexirubins are formed. Devoid of flagellar and gliding motilities. Urease-negative. Nitrate is not reduced to nitrite. Major isoprenoid quinone is MK-6. Major fatty acids are iso- $C_{15: 1}$, iso- $C_{15: 0}$, anteiso- $C_{15: 0}$, $\mathrm{C}_{15: 0}$, iso- $\mathrm{C}_{16: 0}$, summed feature 3 (comprising iso- $\mathrm{C}_{15: 0}$
2-OH and/or $\mathrm{C}_{16: 1} \omega 7 c$ ), iso- $\mathrm{C}_{17: 0} 3-\mathrm{OH}$ and $\mathrm{C}_{17: 0}$ 2-OH. The DNA G+C content is $42.1-44.4 \mathrm{~mol} \%$ (HPLC). Phylogenetically, the genus belongs to the family Flavobacteriaceae. The type species is Salinimicrobium catena.

\section{Description of Salinimicrobium catena (Ying et al. 2007) comb. nov.}

Salinimicrobium catena (ca.te'na. L. n. catena chain, referring to the fact that cells frequently occur in chains).

Basonym: Salegentibacter catena Ying et al. 2007.

The description is given by Ying et al. (2007). The type strain is $\mathrm{HY}^{\mathrm{T}}\left(=\right.$ CGMCC $\left.1.6101^{\mathrm{T}}=\mathrm{JCM} 14015^{\mathrm{T}}\right)$.

\section{Description of Salinimicrobium xinjiangense sp. nov.}

Salinimicrobium xinjiangense (xin.ji.ang.en'se. N.L. neut. adj. xinjiangense of Xinjiang, a region of China).

Displays the following properties in addition to those given in the genus description. Cells are $0.6-1.0 \mu \mathrm{m}$ wide and $1.2-2.4 \mu \mathrm{m}$ long, occurring in chains, but do not produce appendages in older cultures. Colonies are circular, smooth, glistening and convex. Facultatively aerobic. 


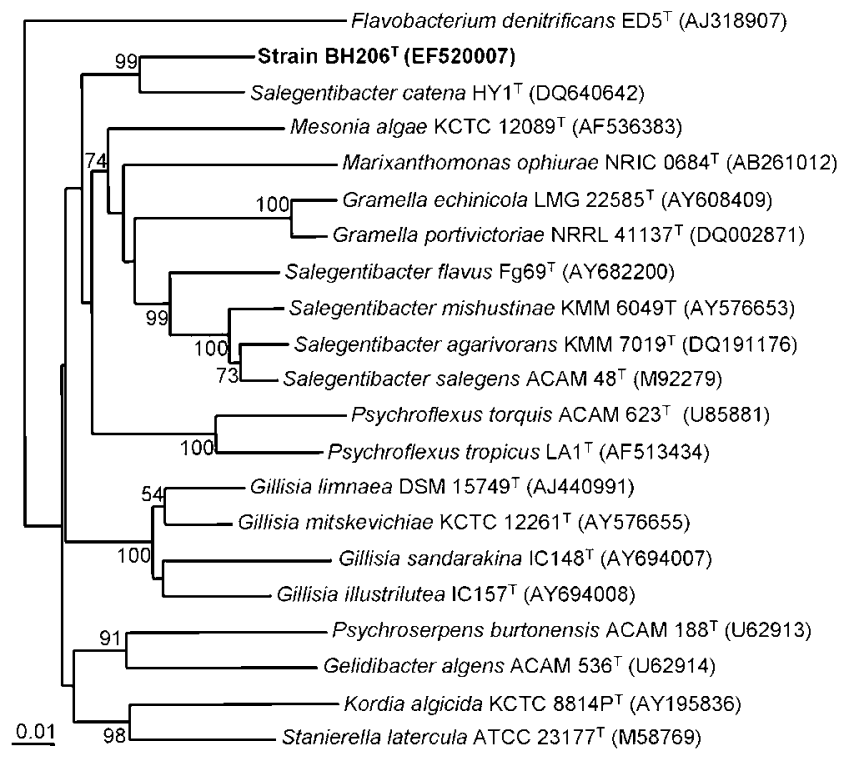

Fig. 1. Neighbour-joining tree based on 16S rRNA gene sequences showing the phylogenetic relationships of strain $\mathrm{BH}_{206}{ }^{\top}$ and related taxa. Bootstrap values are shown as percentages of 1000 replicates, when greater than $50 \%$. Flavobacterium denitrificans $\mathrm{ED}^{\top}{ }^{\top}$ was used as an outgroup. Bar, 0.01 changes per nucleotide position.

Growth occurs at $10-48{ }^{\circ} \mathrm{C}$ (optimum: $32-35{ }^{\circ} \mathrm{C}$ ), $\mathrm{pH} 6.0-$ 9.0 (optimum: $\mathrm{pH} 7.5-8.0$ ) and $0.5-10 \%(\mathrm{w} / \mathrm{v}) \mathrm{NaCl}$ (optimum: 2-3\%). No growth is observed without $\mathrm{NaCl}$. API ZYM gives positive results for alkaline phosphatase, esterase (C4), esterase lipase (C8), leucine arylamidase, valine arylamidase, cystine arylamidase, $\alpha$-chymotrypsin, acid phosphatase, naphthol-AS-BI-phosphohydrolase, $\alpha$ glucosidase, $\beta$-glucosidase and $N$-acetyl- $\beta$-glucosaminidase, but negative results for lipase (C14), trypsin, $\alpha$ galactosidase, $\beta$-galactosidase, $\beta$-glucuronidase, $\alpha$-mannosidase and $\alpha$-fucosidase. Aesculin, casein, starch and Ltyrosine are hydrolysed, but cellulose (CM-cellulose), hypoxanthine, Tween 80 , xanthine and urea are not. Acid is produced from galactose, D-glucose, lactose, maltose and mannose, but not from L-arabinose, D-fructose, glycerol, Dmannitol, melibiose, raffinose, salicin or sucrose. Major cellular fatty acids $(>1 \%$ of the total fatty acids) are iso$\mathrm{C}_{14: 0}(1.47 \%)$, iso- $\mathrm{C}_{15: 1}(1.20 \%)$, iso- $\mathrm{C}_{15: 0}(16.17 \%)$, anteiso- $\mathrm{C}_{15: 0} \quad(11.98 \%), \quad \mathrm{C}_{15: 0} \quad(4.81 \%), \quad$ iso- $\mathrm{C}_{16: 1}$ $(1.93 \%)$, iso- $\mathrm{C}_{16: 0}(10.21 \%)$, summed feature 3 (comprising iso- $\mathrm{C}_{15: 0} 2-\mathrm{OH}$ and/or $\left.\mathrm{C}_{16: 1} \omega 7 c ; 6.78 \%\right), \mathrm{C}_{16: 0}$ $(1.07 \%)$, iso- $\mathrm{C}_{15: 0} 3-\mathrm{OH}(1.70 \%), \mathrm{C}_{15: 0} 2-\mathrm{OH}(2.23 \%)$, iso- $\mathrm{C}_{17: 1} \omega 9 c(8.66 \%)$, anteiso- $\mathrm{C}_{17: 1} \omega 9 c \quad(5.86 \%)$, iso$\mathrm{C}_{17: 0} \quad(1.03 \%)$, anteiso- $\mathrm{C}_{17: 0} \quad(1.26 \%), \quad \mathrm{C}_{17: 1} \omega 6 c$ $(2.10 \%)$, iso- $\mathrm{C}_{16: 0} \quad 3-\mathrm{OH} \quad(1.86 \%)$, iso- $\mathrm{C}_{17: 0} \quad 3-\mathrm{OH}$ $(8.18 \%)$ and $\mathrm{C}_{17: 0} 2-\mathrm{OH}(6.17 \%)$.

The type strain is $\mathrm{BH}_{206}{ }^{\mathrm{T}} \quad\left(=\mathrm{KCTC} \quad 12883^{\mathrm{T}}=\mathrm{DSM}\right.$ $19287^{\mathrm{T}}$ ), isolated from a salt lake in China.

\section{Acknowledgements}

This work was supported by the 21C Frontier Microbial Genomics and Application Center Program, Ministry of Science \& Technology, and by the Korea Foundation for International Cooperation of Science \& Technology (KICOS) through a grant provided by the Korean Ministry of Science \& Technology (MOST) in Global Partnership Program (No. M60602000001-06E0200-00100).

\section{References}

Bernardet, J. F., Nakagawa, Y. \& Holmes, B. (2002). Proposed minimal standards for describing new taxa of the family Flavobacteriaceae and emended description of the family. Int J Syst Evol Microbiol 52, 1049-1070.

Carrasco, I. J., Márquez, M. C., Yanfen, X., Ma, Y., Cowan, D. A., Jones, B. E., Grant, W. D. \& Ventosa, A. (2006). Gracilibacillus orientalis sp. nov., a novel moderately halophilic bacterium isolated from a salt lake in Inner Mongolia, China. Int J Syst Microbiol 56, 599-604.

Cole, J. R., Chai, B., Marsh, T. L., Farris, R. J., Wang, Q., Kulam, S. A., Chandra, S., McGarrell, D. M., Schmidt, T. M. \& other authors (2003). The ribosomal database project (RDP-II): previewing a new autoaligner that allows regular updates and the new prokaryotic taxonomy. Nucleic Acids Res 31, 442-443.

Dobson, S. J., Colwell, R. R., Franzmann, P. D. \& McMeekin, T. A. (1993). Direct sequencing of the PCR-amplified 16S rRNA gene of Flavobacterium gondwanense sp. nov. and Flavobacterium salegens sp. nov., two new species from a hypersaline Antarctic lake. Int J Syst Bacteriol 43, 77-83.

Felsenstein, J. (2002). PHYLIP (phylogeny inference package), version 3.6a. Distributed by the author. Department of Genome Science, University of Washington, Seattle, USA. http://evolution.genetics.washington.edu/phylip.html

Gomori, G. (1955). Preparation of buffers for use in enzyme studies. Methods Enzymol 1, 138-146.

Ivanova, E. P., Bowman, J. P., Christen, R., Zhukova, N. V., Lysenko, A. M., Gorshkova, N. M., Mitik-Dineva, N., Sergeev, A. F. \& Mikhailov, V. V. (2006). Salegentibacter flavus sp. nov. Int J Syst Evol Microbiol 56, 583-586.

Jeon, C. O., Lim, J.-M., Lee, J. M., Xu, L. H., Jiang, C. L. \& Kim, C.-J. (2005). Reclassification of Bacillus haloalkaliphilus Fritze 1996 as Alkalibacillus haloalkaliphilus gen. nov., comb. nov. and the description of Alkalibacillus salilacus sp. nov., a novel halophilic bacterium isolated from a salt lake in China. Int J Syst Evol Microbiol 55, 1891-1896.

Kimura, M. (1980). A simple method for estimating evolutionary rates of base substitutions through comparative studies of nucleotide sequences. J Mol Evol 16, 111-120.

Komagata, K. \& Suzuki, K. (1987). Lipid and cell-wall analysis in bacterial systematics. Methods Microbiol 19, 161-207.

Lane, D. J. (1991). 16S/23S rRNA sequencing. In Nucleic Acid Techniques in Bacterial Systematics, pp. 115-175. Edited by E. Stackebrandt \& M. Goodfellow. Chichester: Wiley.

Lanyi, B. (1987). Classical and rapid identification methods for medically important bacteria. Methods Microbiol 19, 1-67.

Leifson, E. (1963). Determination of carbohydrate metabolism of marine bacteria. J Bacteriol 85, 1183-1184.

McCammon, S. A. \& Bowman, J. P. (2000). Taxonomy of Antarctic Flavobacterium species: description of Flavobacterium gillisiae sp. nov., Flavobacterium tegetincola sp. nov. and Flavobacterium xanthum sp. nov., nom. rev. and reclassification of [Flavobacterium] salegens as 
Salegentibacter salegens gen. nov., comb. nov. Int J Syst Evol Microbiol 50, 1055-1063.

Nedashkovskaya, O. I., Kim, S. B., Han, S. K., Lysenko, A. M., Rohde, M., Zhukova, N. V., Falsen, E., Frolova, G. M., Mikhailov, V. V. \& Bae, K. S. (2003). Mesonia algae gen. nov., sp. nov., a novel marine bacterium of the family Flavobacteriaceae isolated from the green alga Acrosiphonia sonderi (Kütz) Kornm. Int J Syst Evol Microbiol 53, 1967-1971.

Nedashkovskaya, O. I., Suzuki, M., Vancanneyt, M., Cleenwerck, I., Zhukova, N. V., Vysotskii, M. V., Mikhailov, V. V. \& Swings, J. (2004). Salegentibacter holothuriorum sp. nov., isolated from the edible holothurian Apostichopus japonicus. Int J Syst Evol Microbiol 54, $1107-1110$

Nedashkovskaya, O. I., Kim, S. B., Lysenko, A. M., Mikhailov, V. V., Bae, K. S. \& Kim, I. S. (2005a). Salegentibacter mishustinae sp. nov., isolated from the sea urchin Strongylocentrotus intermedius. Int J Syst Evol Microbiol 55, 235-294.

Nedashkovskaya, O. I., Kim, S. B., Lee, K. H., Mikhailov, V. V. \& Bae, K. S. (2005b). Gillisia mitskevichiae sp. nov., a novel bacterium of the family Flavobacteriaceae, isolated from sea water. Int J Syst Evol Microbiol 55, 321-323.

Nedashkovskaya, O. I., Kim, S. B., Vancanney, M., Shin, D. S., Lysenko, A. M., Shevchenko, L. S., Krasokhin, V. B., Mikhailov, V. V.,
Swings, J. \& Bae, K. S. (2006). Salegentibacter agarivorans sp. nov., a novel marine bacterium of the family Flavobacteriaceae isolated from the sponge Artemisina sp. Int J Syst Evol Microbiol 56, 883-887.

Smibert, R. M. \& Krieg, N. R. (1994). Phenotypic characterization. In Methods for General and Molecular Bacteriology, pp. 607-654. Edited by P. Gerhardt, R. G. E. Murray, W. A. Wood \& N. R. Krieg. Washington, DC: American Society for Microbiology.

Tamaoka, J. \& Komagata, K. (1984). Determination of DNA base composition by reversed-phase high-performance liquid chromatography. FEMS Microbiol Lett 25, 125-128.

Thompson, J. D., Higgins, D. G. \& Gibson, T. J. (1994). CLUSTAL W: improving the sensitivity of progressive multiple sequence alignment through sequence weighting, position-specific gap penalties and weight matrix choice. Nucleic Acids Res 22, 4673-4680.

Van Trappen, S., Vandecandelaere, I., Mergaert, J. \& Swings, J. (2004). Gillisia limnaea gen. nov., sp. nov., a new member of the family Flavobacteriaceae isolated from a microbial mat in Lake Fryxell, Antarctica. Int J Syst Evol Microbiol 54, 445-448.

Ying, J.-Y., Liu, Z.-P., Wang, B.-J., Dai, X., Yang, S.-S. \& Liu, S.-J. (2007). Salegentibacter catena sp. nov., isolated from sediment of the South China Sea, and emended description of the genus Salegentibacter. Int J Syst Evol Microbiol 57, 219-222. 